University of Nebraska - Lincoln

DigitalCommons@University of Nebraska - Lincoln

1996

\title{
Estimation of Seasonal Dynamics of Pasture and Crop Productivity in Kazakhstan Using NOAA/AVHRR Data
}

\author{
Anatoly A. Gitelson \\ University of Nebraska - Lincoln, agitelson2@unl.edu \\ Felix Kogan \\ National Environmental Satellite Data and Information Service, National Oceanic and Atmospheric \\ Administration, felix.kogan@noaa.gov \\ Lev Spivak \\ Institute for Space Research, Academy of Sciences, Kazakhstan \\ Edige Zakarin \\ Institute for Space Research, Academy of Sciences, Kazakhstan \\ Lubov Lebed \\ National Meteorological Administration, Kazakhstan
}

Follow this and additional works at: https://digitalcommons.unl.edu/natrespapers

Part of the Natural Resources and Conservation Commons

Gitelson, Anatoly A.; Kogan, Felix; Spivak, Lev; Zakarin, Edige; and Lebed, Lubov, "Estimation of Seasonal Dynamics of Pasture and Crop Productivity in Kazakhstan Using NOAA/AVHRR Data" (1996). Papers in Natural Resources. 234.

https://digitalcommons.unl.edu/natrespapers/234

This Article is brought to you for free and open access by the Natural Resources, School of at DigitalCommons@University of Nebraska - Lincoln. It has been accepted for inclusion in Papers in Natural Resources by an authorized administrator of DigitalCommons@University of Nebraska - Lincoln. 


\title{
Estimation of Seasonal Dynamics of Pasture and Crop Productivity in Kazakhstan Using NOAA/AVHRR Data
}

\author{
Anatoly Gitelson $^{\alpha}$, Felix Kogan $^{\beta}$, Lev Spivak ${ }^{\chi}$, Edige Zakarin $^{x}$, Lubov Lebed ${ }^{\varepsilon}$ \\ ${ }^{\alpha}$ J. Blaustein Institute for Desert Research, Ben-Gurion University of the Negev, 84990 Israel; Phone: (972)-7-557 219; \\ Fax: (972)-7-557 042; Email: gitelson@bgumail.bgu.ac.il; ' National Environmental Satellite Data and Information \\ Service, National Oceanic and Atmospheric Administration, USA; Institute for Space Research, Academy of Sciences, \\ Kazakhstan. National Meteorological Administration, Kazakhstan
}

\begin{abstract}
Recently, NOAA developed the AVHRR-based Vegetation Condition Index (VCI) for drought monitoring. This index was used for estimating pasture and crop productivity in Kazakhstan. The results of VCI-derived vegetation conditions were compared with vegetation density, biomass and reflectance measured in different climatic and ecological zones with elevation from 200 to $700 \mathrm{~m}$ and a large range of the NDVI variation (over space and season) from 0.05 to 0.47. An estimation error of AVHRR-derived vegetation density was less than 16 per cent. First time it was shown that the VCI-derived vegetation condition data can be effectively used for quantitative assessments of both vegetation state and productivity (density and biomass) over large areas.
\end{abstract}

\section{INTRODUCTION}

Drought is the typical phenomenon of the Kazakh climate which occurs every two to four years. In order to mitigate drought consequences thorough monitoring of drought start, expansion and duration is required. The goal of the work was to develop and test algorithms for using data obtained by the Advanced Very High Resolution Radiometer (AVHRR) flown on NOAA polar orbiting satellites for quantitative monitoring seasonal dynamics of pasture and crop conditions and production in Kazakhstan. In the paper we present comprehensive results of the validation of AVHRR-derived vegetation conditions with actually measured vegetation density.

\section{DATA AND METHODS}

Satellite data set contained Global Vegetation Index (16 $\mathrm{km}$ spatial resolution, 7 days temporal resolution) from NOAA-9, NOAA-11, and NOAA-14 (Ohring et al., 1989) in a period from 1985 to 1995 . Ground data included historical set for the period from 1985 to 1995 on 10-day total precipitation $(\mathrm{mm})$, average temperature, end of 10 -day soil moisture, phenology and vegetation density (number of plants per square meter) from six weather stations located in different climatic zones of Kazakhstan. During the growing seasons of 1994 and 1995, the biomass of winter wheat and spring barley (three plots) and that of grass (four plots) were measured at two weather stations in Almaty region. Simultaneously upwelling radiance of vegetation and reference white plate were measured with hand-held radiometer in twenty different locations of each plot and average and median values were calculated. These measurements were made in the spectral bands corresponding to the red and near infra-red channels of the AVHRR sensor. The reflectance were determined as ratio of upwelling radiance of vegetation to that of reference plate. NDVI variation over space were studied also using airborne radiometer in the channels of NDVI.

The highest and the lowest NDVI values during 19851995 for each of the 52 weeks of the year and for each pixel was calculated. The weather component of the NDVI was enhanced by separating it from the ecosystem component [13]. The weather-related NDVI envelope was linearly scaled from zero (minimum NDVI) to 100 (maximum NDVI) for each grid cell and week. The resulting index was named the Vegetation Condition Index (VCI) defined by the following:

$$
\begin{gathered}
\mathrm{VCI}=\left(\mathrm{NDVI}^{-\mathrm{NDVI}_{\mathrm{med}}}\right) / \\
\left(\mathrm{NDVI}_{\mathrm{max}}-\mathrm{NDVI}_{\mathrm{min}}\right)
\end{gathered}
$$

where NDVI, NDVI max and NDVI min are the smoothed weekly NDVI [4], its multi-year maximum, and multi-year minimum, respectively, calculated for each pixel.

The average VCI data for the area of $48 \mathrm{~km}$ by $48 \mathrm{~km} \mathrm{(3}$ by $3 \mathrm{GVI}$ pixels) were collected around six weather stations with the experimental plots. These stations are located in southern (Almaty region), central (Jeskazgan), and northern (Akmola) Kazakhstan. Analysis was done for two years with different weather conditions, 1991 dry and 1992 wet. Data on density of vegetation were measured several times ( 5 to 11) for the growing season in a period from 1985 to 1995 . For comparison with VCI, the ground measurements of density were expressed in terms of multi-year variation. Each measurement, $D_{i}$, was expressed as a deviation from median, $\mathrm{D}_{\text {med }}$, values and normalized to the range of multi-year fluctuation of the density, $\left(D_{\max }-D_{\min }\right)$ :

$$
\delta \mathrm{D},(\%)=\left(\mathrm{D}_{\mathrm{i}}-\mathrm{D}_{\mathrm{med}}\right) /\left(\mathrm{D}_{\max }-\mathrm{D}_{\min }\right)
$$



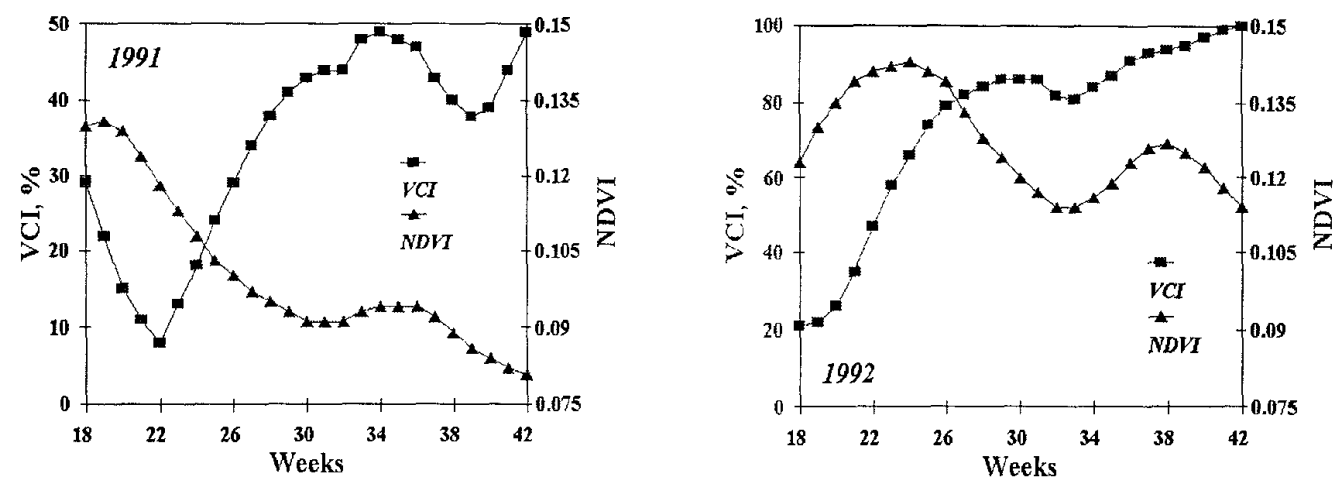

Fig 1. NDVI and VCI dynamics at station 36819 (Almaty region) in 1991 (dry) and 1992 (favorable conditions).

\section{RESULTS AND DISCUSSION}

NDVI and VCI dynamics on one of the test sites in Kazakhstan during two years with extremely different weather conditions are shown in Fig. 1. Although NDVI had very similar dynamics during these years, the VCI indicates that the dynamics of vegetation conditions were very different and VCI values in 1992 were two to three times larger than in 1991.

The attempt was made to find out whether AVHRRderived VCI can be used as an quantitative indicator of vegetation productivity on a large area. The good match between VCI- and density-derived conditions shown in Figs. 2 and 3. Despite of the fact that six selected stations were located in very different climatic and ecological zones, with elevation changing from 300 to $700 \mathrm{~m}$ and a large range of NDVI variation (over space and season) from 0.05 to 0.47 , all station points were located around the same correlation line (Fig. 4). Although there are some local differences, correlation was high $\mathrm{r}^{2}=0.76$ with an estimating error of vegetation density of less than 16 percent. This error is less for low density, indicating that in cases of very unfavorable weather (such as drought) the accuracy of VCI-derived estimates is higher. One of the main causes for scattering of the VCI vs. Density relationship may be the difference between aerial estimates from satellite data and point measurements of ground density.
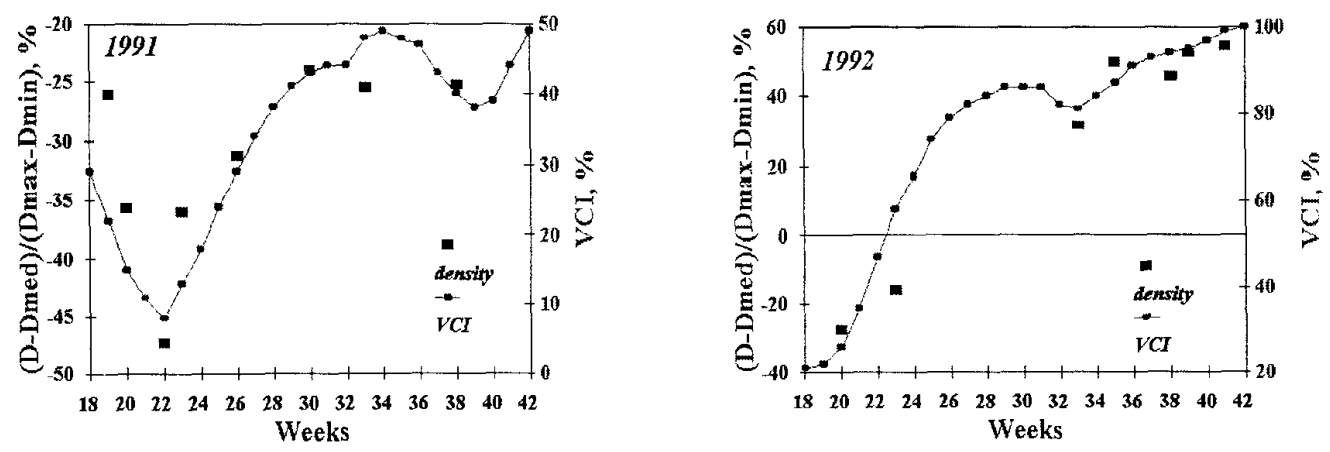

Fig. 2. Comparison of the VCI and multi-year density variation from median values in 1991 and 1992. Station 36819 (Almaty region) 


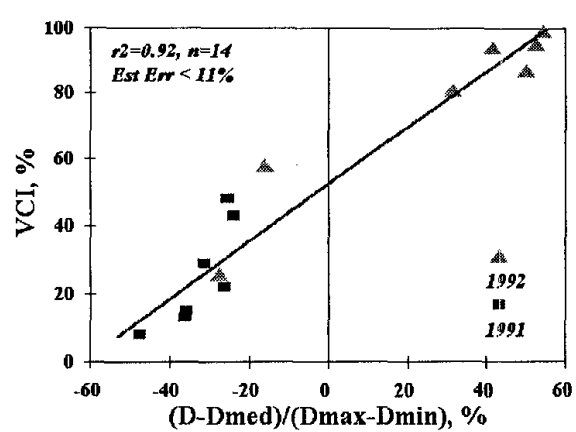

Fig. 3. Correlation between the VCI derived and actually measured density of vegetation. Station 36819 (Almaty region).

The findings are the first step in validating the VCI. First time it was shown that the VCI-derived vegetation condition data can be effectively used for quantitative assessments of density and biomass of vegetation over large areas.

\section{REFERENCES}

[1] Kogan, F.N., "Remote sensing of weather impacts on vegetation in non-homogeneous areas," Int. Journal of Remote Sensing, vol. 11, pp. 1405-1419, 1990.

[2] Kogan, F.N., "NOAA plays leadership role in developing satellite technology for drought watch," Earth Observation Magazine, September 1994, pp. 18-21, 1994.

[3] Kogan, F.N., "Drought of the late 1980s in the United States as derived from NOAA polar-orbiting satellite data," Bul. Of the Amer. Met. Soc., vol. 76, pp. 1-13, 1995.

[4] Ohring, G., K. Gallo, A. Gruber, W. Planet, L. Stowe, J.D. Tarpley, "Climate and Global Change: Characteristics of NOAA Satellite Data," Eos. Trans., Amer. Geophysical Union, vol. 70, pp. 889-901, 1989.

[5] Tucker, C.J., J.R.G. Townshend, T.E. Goff, "African Land Cover Classification Using Satellite Data," Science, vol. 227, No. 4685, January 25, pp. 369-375, 1985.

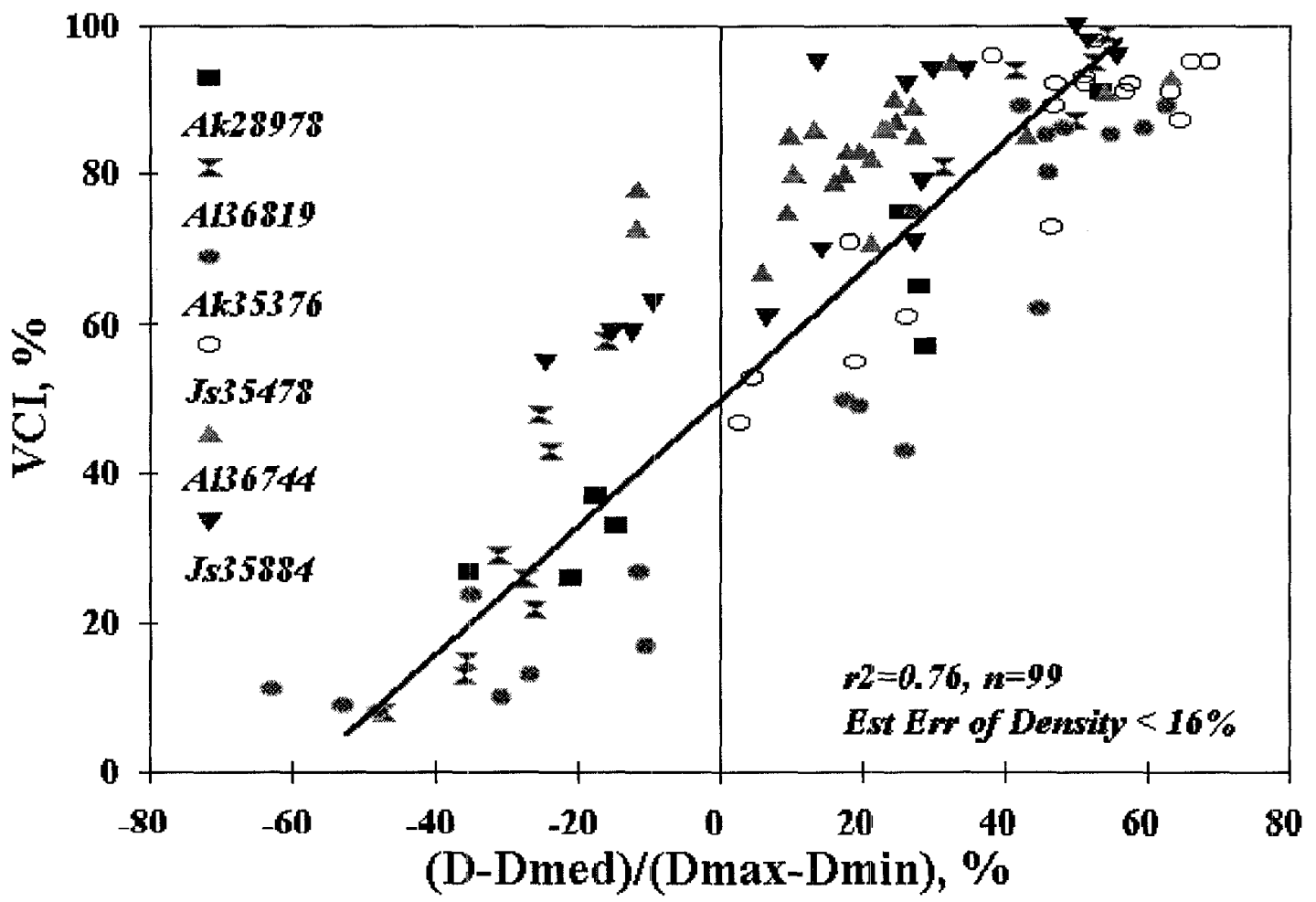

Fig. 4. Correlation between the VCI-derived and actually measured density of vegetation for six weather stations and for two years (1991 and 1992). 